\title{
Calendar Anomalies: The Case of Amman Stock Exchange
}

\author{
Dima Waleed Hanna Alrabadi ${ }^{1} \&$ Kamal Ahmad AL-Qudah ${ }^{2}$ \\ ${ }^{1}$ Faculty of Economics and Business Administration, Yarmouk University, Jordan \\ ${ }^{2}$ Faculty of Business and Finance, American University of Madaba, Jordan \\ Correspondence: Dima Waleed Hanna Alrabadi, Finance and Banking Sciences Department, Faculty of \\ Economics and Business Administration, Yarmouk University, P.O Box 566, Irbid 21163, Jordan. Tel: \\ 96-22-721-1111 ext. 6856. E-mail: dhws2004@yahoo.co.uk
}

Received: September 1, 2012 Accepted: September 28, 2012 Online Published: November 28, 2012

doi:10.5539/ijbm.v7n24p120 URL: http://dx.doi.org/10.5539/ijbm.v7n24p120

\begin{abstract}
This study examines calendar anomalies in Amman Stock Exchange (ASE) over the period 2002-2011. Specifically, we investigate the day of the week, month of the year, and turn of the month effects. We use monthly and daily returns of the free float market index. Our findings indicate that returns are significantly higher on Sundays (the first day of trading of the week) and Thursdays (the last trading day of the week) than other days of the week. Moreover a highly significant January effect exists. Finally, we find that most returns happen on the turn of the month rather than during the rest of it. These results are useful to Jordanian investors who can formulate their investment strategies accordingly.
\end{abstract}

Keywords: efficient market hypothesis, alendar anomalies, day of the week effect, January effect, turn of the month effect, Amman stock exchange

\section{Introduction}

The Efficient market hypothesis of Fama (1970) is beaten by several anomalies. Calendar anomalies are of vital importance and found to exist in most stock exchanges around the world. They indicate that there is some regularity in return patterns which enable investors to formulate their investment strategies accordingly and achieve abnormal returns. This study focuses on three calendar anomalies, day of the week, month of the year (January effect), and turn of the month effects. The day of the week effect indicates that Monday returns are lower than the returns of other week days (Cross, 1973; French, 1980; Gibbons and Hess, 1981; Lakonishok and Levi, 1982). Literature suggests a number of hypotheses to explain the presence of this seasonality: specifically, an information release hypothesis, whereby firms delay the release of negative information until the end of the week, a settlement regime hypothesis, related to differences in the timing of transactions and settlement, and an information processing hypothesis associated with the asymmetry in information costs across small and large investors. January effect is another well-known calendar anomaly which indicates that returns in January are the largest comparing to the returns in other months of the year (Rozeff and Kinney, 1976). This is explained mainly by tax-loss hypothesis which assumes that investors sell their loosed securities to decrease their taxes at the end of the year and return to long positions at the beginning of the following year. Turn of the month effect indicates that most returns are achieved on the turning days of the month (Ariel, 1987). Two arguments are mainly put forward to explain this anomaly. First, Companies usually declare profits during the first fortnight of the month. Second, end-of-the month prices increase is attributable to better purchasing power resulting from salaries that are usually paid at the end of the month. This study investigates these three calendar anomalies in Amman Stock Exchange (ASE) over the period 2002-2011. Our methodology is based on regression estimated using both OLS and GARCH models. The Jordanian evidence on this issue is poor somehow. Maghayereh (2003) finds no significant differences in monthly returns using GARCH models over the period 1994-2002. Using the same methodology, Al-Rjoub (2004) finds that returns are largest on Thursdays and worst on Mondays. However, Al-Rjoub's sample period also ends in 2002. Finally, Al-Jarrah et al. (2011) find no significant turn of the month or January anomalies over the period 1992-2007. Nevertheless, they only depend on paired t-statistic to investigate the differences in returns. Our findings can be summarized as follows: returns are significantly higher on Sundays and Thursdays than other days of the week. A highly significant January effect exists. Most returns happen on the turn of the month rather than during the rest of it. The paper structured in this manner. Section 2 reviews the related literature. Section 3 outlines the data and the methodology adopted. Empirical results are 
reported and discussed in section 4. Finally conclusions are presented in section 5.

\section{Literature Review}

Our review of literature will include three sections, each reviewing the studies of a certain calendar anomaly.

\subsection{Day of the Week Anomaly}

Cross (1973), French (1980), Gibbons and Hess (1981), Lakonishok and Levi (1982), Keim and Stambaugh (1984), Lakonishok and Smidt (1988), Connolly (1989) and Lakonishok and Maberly (1990) are the pioneering papers who introduced the day of the week effect. They find that Mondays are bad days for the US stocks compared to other days of the week. In particular, they find that the average returns on Monday are negative, while the average returns on Friday are high. Researchers provide an international supporting evidence of the day of the week effect. Jafe and Westerfield (1985) examine the weekend effect in Australian, Canadian, Japanese and UK equity markets, and find that the lowest mean returns for both Japanese and Australian stock markets were on Tuesdays. Solnik and Bousquet (1990) also exhibit a strong and continual negative return on Tuesday in the case of the Paris Bourse. Barone (1990) validate these results that identified the biggest decrease in Italian stock prices regularly on Tuesday. Mills and Couts (1995) and Arsad and Coutts (1996) find significant day of the week effect in UK. Apolonario et al. (2006) provide evidence of the day of the week effect for the European stock markets. The evidence is also found in developing countries. Choudhry (2000) analyzes this phenomenon on seven emerging Asian stock markets including India, Indonesia, Malaysia, the Philippine, South Korea, Taiwan, and Thailand. His findings demonstrate existence of the day of the week effect on both returns and volatility. Similar results are found by Hui (2005) for the Asia pacific stock markets. Rodriguez (2012) document significant evidence of a Monday Effect (lower than expected returns) and a Friday Effect (higher than expected returns) in Latin America (specifically in Argentina, Brazil, Chile, Colombia, Mexico and Peru). On the other hand, some studies find no significant negative Monday returns in Belgium, the Netherlands and Sweden (Agrawal and Tandon, 1994), Spain (Pena, 1995), Greece (Alexakis and Xanthakis, 1995), South Korea and the Philippines (Brooks and Persand, 2001).

\subsection{Month of the Year Effect}

Rozeff and Kinney (1976), Dyl (1977) and Brown et al. (1983) are the first who uncover significant higher returns in January than in the other months of the year in the US stock market. Following research detect the same phenomenon in both developed and emerging markets around the world. Gultekin and Gultekin (1983) study seventeen industrialized countries using both non-parametric and parametric tests, and conclude that January returns are significantly higher when compared with the other months, in thirteen of those countries. Aggarwal and Rivoli (1989) examine whether January effects exist in four emerging markets, Hong Kong, Singapore, Malaysia, and the Philippine. They find confirming evidence except for the Philippines. Ho (1990) examines twelve stock markets, including Australia, Japan, Korea, New Zealand, Singapore, Thailand, UK and US, and finds consistent evidence of the January effect. Arsad and Coutts (1997) and Choudhry (2001) find significant January effect in the UK stock market. Mehdian and Perry (2002) investigate the January effect in three US market indexes from 1964-1998: Dow Jones Composite, NYSE Composite and the SP500. They find positive and significant January returns in all three stock market indexes prior to 1987, the effect disappears thereafter. On the other hand, Fountas and Segredakis (2002) investigate the month of the year effect in eighteen emerging equity markets. They observe that stock returns for January were significantly higher than the returns for the remaining eleven months only in Chile, Greece, Korea, Taiwan and Turkey. Doran et al. (2008) and Rezvanian et al. (2008) find no significant January effect in the Chinese stock market. Giovanis (2009) examine fifty five stock markets and the January effect is rejected, as it is presented only in seven stock markets, while the most frequent significant higher monthly returns are reported in December of twelve stock markets. Keong et al (2010) study the same issue in eleven Asian countries- Hong Kong, India, Indonesia, Japan, Malaysia, Korea, Philippines, Singapore, Taiwan, China and Thailand using GARCH $(1,1)$ model. They find positive December effect, except for Hong Kong, Japan, Korea, and China. Only some countries do have positive January, April, and May effect and just Indonesia demonstrates negative August effect. Marrett and Worthington (2011) examine the month of the year effect in the Australian stock market. Their results show that returns are significantly higher in April, July and December along with evidence of a small cap effect with systematically higher returns in January, August and December. Patel (2012) find that the January effect no longer exists for many developed and emerging markets.

\subsection{Turn of the Month Effect}

Ariel (1987) is the one who discover the seasonal turn of the month pattern in the US market. Lakonishok and Smidt (1988), Ogden (1990), and Pettengill and Jordan (1988) provide supporting evidence of the turn of the 
month effect in the same market. Cadsby and Radner (1992) examine the same issue and holiday evidence in 69 daily stock market indices of 10 countries between 1962 and 1989. They find evidence of significant turn-of-month effect in Canada, UK, Australia, Switzerland, and West Germany that is independent of the turn-of-the-year effect. Boudreaux (1995) also find consistent results in the international stock markets. Kunkel (2003) examines turn of the month anomaly for stock market indices in 19 developed and emerging countries. Using both parametric and nonparametric measures, they find that the 4-day turn of the month accounts for $87 \%$ of the monthly return, on average, across 15 of the examined countries.

However, other authors find no significant turn of the month effect in different stock markets. Jaffe \& Westerfield (1989) document weak evidence of the turn of the month effect in the Australian stock market. Mills et al. (2000) study calendar effects in the individual stocks as well as in the general index of Athens Stock Exchange from October 1986 to April 1997. They find that calendar anomalies differ for various stocks on the basis of capitalization, beta coefficients and company type. McGuinness (2006) demonstrates that the turn of the month effect is unique only to the small cap stock in the Hong Kong exchange. Floros (2008) find no statistically significant returns on the turn of the month in the same market.

\section{Data and Methodology}

Our data set consists of the daily and monthly returns of ASE free float market index over the period 2002-2011. The methodology is mainly based on regression analysis with dummy variables. The day-of-the-week effect is examined through estimating the following time series regression model which includes five dummy variables, one for each day of the week:

$$
R_{m t}=\beta_{1} D_{1 t}+\beta_{2} D_{2 t}+\beta_{3} D_{3 t}+\beta_{4} D_{4 t}+\beta_{5} D_{5 t}+\delta A R(1)+e_{t}
$$

$R_{m t}$ is the market return on day $t$.

$D_{j t}$ : are dummy variables which take on the value 1 if the corresponding day is a Sunday, Monday, Tuesday, Wednesday or Thursday, respectively and 0 otherwise. $A R(1)$ is added to account for the lagged effect of market return. The model is estimated without an intercept in order to avoid the dummy variable trap (for more information, see Gujarati, 2004).

The month of the year effect is examined through estimating the following time series regression model which includes twelve dummy variables, one for each month of the year:

$$
R_{m t}=\beta_{1} D_{1 t}+\beta_{2} D_{2 t}+\beta_{3} D_{3 t}+\ldots \ldots . .+\beta_{12} D_{12 t}+\delta A R(1)+e_{t}
$$

$R_{m t}$ is the market return on month $t$.

$D_{j t}$ : are dummy variables which take on the value 1 if the corresponding month is January, February, March, ..., or December, respectively and 0 otherwise.

Finally, the turn of the month effect is investigated by estimating the following time series regression model:

$$
R_{m t}=\alpha+\beta_{1 t} D_{1 t}+e_{i t}
$$

$R_{m t}$ is the market return on day $t$.

$D_{j t}$ is a dummy variable that takes a value of one if the corresponding day is the last trading day in a month or one of the three trading days in the beginning of the following month.

Two approaches are used to estimate the three models, OLS with Newey-West HAC Standard Errors and Covariance in order to account for heteroskedasticity and serial correlation in the obtained residuals and GARCH $(1,1)$ as a standard model to control for heteroskedasticity.

\section{Empirical Results}

Table 1 shows descriptive statistics of the market return over the study period. The mean daily return is zero while the mean monthly return is .005 . The return values show small deviations from mean. The standard deviation is $1 \%$ on a daily basis and $5.8 \%$ on a monthly basis. Figure 1 show the behavior of market return over the study period. 
Table 1. The descriptive statistics of the market return over the study period

\begin{tabular}{lcc}
\hline Stats & Daily & Monthly \\
\hline Mean & 0.000 & 0.005 \\
Median & 0.001 & 0.000 \\
Maximum & 0.047 & 0.150 \\
Minimum & -0.045 & -0.250 \\
Std. Dev. & 0.010 & 0.058 \\
\hline
\end{tabular}

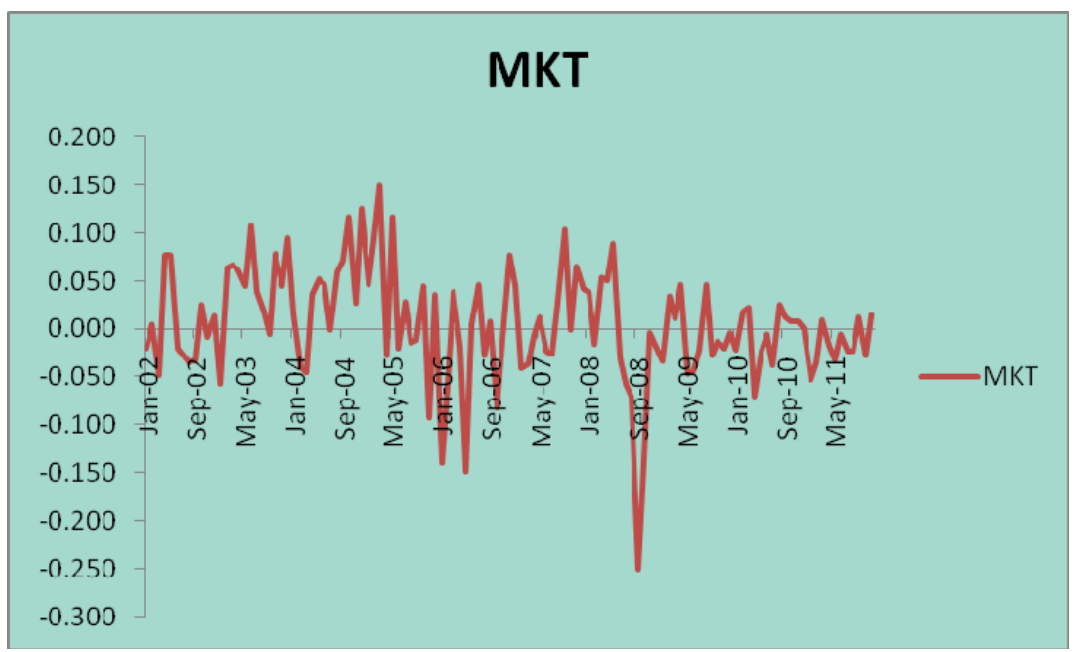

Figure 1. The behavior of market return over the study period

Table 2 shows the daily average and sum returns over the study period. The results indicate that market return is highest on Sunday (the first trading day in the week in ASE); the following is Thursday (the last trading day in the week in ASE). Thus, market return seems to be high at the beginning and ending of the week and near to zero or negative in its middle. The regression analysis in Table 3 shows consistent results. The results of both OLS and GARCH $(1,1)$ show a significant day of the week effect. The returns on Sundays and Thursdays are highly significant and positive. On the other hand, Monday returns are significant and negative. Using GARCH models, Al-Rjoub (2004) finds that over the period 2002-2004, Thursday return is highest and positive while Monday return is the worst and negative. The start-of-the-week day returns are insignificantly negative.

Table 2 . The daily average and sum returns over the study period

\begin{tabular}{cccccc}
\hline Day & Sun & Mon & Tues & Wed & Thurs \\
\hline SUM & 0.877 & -0.802 & -0.028 & -0.099 & 0.642 \\
AVG & 0.002 & -0.002 & 0.000 & 0.000 & 0.001 \\
\hline
\end{tabular}

Table 3. The results of regression analysis

\begin{tabular}{ccccc}
\hline Variable & OLS Coefficient & Prob. & GARCH Coefficient & Prob. \\
\hline SUN & 0.002 & 0.002 & 0.002 & 0.000 \\
MON & -0.002 & 0.001 & -0.001 & 0.079 \\
TUS & 0.000 & 0.876 & 0.000 & 0.444 \\
WED & 0.000 & 0.585 & 0.000 & 0.977 \\
THURS & 0.001 & 0.001 & 0.001 & 0.000 \\
AR(1) & 0.236 & 0.000 & 0.217 & 0.000 \\
Adjusted R squared & 0.066 & & & \\
\hline
\end{tabular}


Table 4 reports the sum and average returns on a monthly basis over the period of the study. The results show that market returns are highest in January confirming the January effect. Moreover, the OLS and GARCH regression results in Table 5 show a highly significant January effect. The coefficients of the other months of the year are insignificant. These findings contradict Maghayereh (2003) who find no evidence of monthly seasonality as well as January effect in the ASE returns over the period 1994-2002, using the standard GARCH, exponential GARCH (EGARCH) and the GJR models.

Table 4. The sum and average returns on a monthly basis over the period of the study

\begin{tabular}{ccccccccccccc}
\hline Month & Jan & Feb & Mar & Apr & May & Jun & Jul & Aug & Sep & Oct & Nov & Dec \\
\hline SUM & 0.370 & -0.177 & 0.033 & 0.224 & 0.133 & 0.145 & 0.010 & -0.078 & 0.010 & -0.117 & 0.017 & 0.029 \\
AVG & 0.041 & -0.018 & 0.003 & 0.022 & 0.013 & 0.015 & 0.001 & -0.008 & 0.001 & -0.012 & 0.002 & 0.003 \\
\hline
\end{tabular}

Table 5. The OLS and GARCH regression results

\begin{tabular}{ccccc}
\hline Variable & OLS Coefficient & Prob. & GARCh Coefficient & Prob. \\
\hline JAN & 0.042 & 0.010 & 0.018 & 0.023 \\
FEB & -0.017 & 0.386 & -0.033 & 0.085 \\
MAR & 0.004 & 0.827 & -0.009 & 0.511 \\
APR & 0.022 & 0.236 & 0.014 & 0.483 \\
MAY & 0.013 & 0.414 & -0.016 & 0.223 \\
JUN & 0.015 & 0.557 & -0.019 & 0.188 \\
JUL & 0.001 & 0.942 & 0.001 & 0.970 \\
AUG & -0.008 & 0.485 & -0.016 & 0.607 \\
SEP & 0.001 & 0.946 & 0.004 & 0.797 \\
OCT & -0.012 & 0.693 & 0.002 & 0.873 \\
NOV & 0.002 & 0.941 & -0.005 & 0.647 \\
DEC & 0.003 & 0.839 & 0.008 & 0.682 \\
AR(1) & 0.350 & 0.001 & 0.352 & 0.006 \\
Adjusted R squared & 0.086 & & & \\
\hline
\end{tabular}

Table 6 indicates a significant turn of the month effect. Thus, most returns are achieved within the last day of a certain month and the three working days at the beginning of the following month. These findings contrast those of Al-Jarrah et al. (2011). They find no significant turn of the month effect in ASE over the period January 1, 1992 through September 6, 2007 using paired t-test.

Table 6. Significant turn of the month effect

\begin{tabular}{ccccc}
\hline Variable & OLS Coefficient & Prob. & GARCH Coefficient & Prob. \\
\hline C & 0.001 & 0.134 & 0.001 & 0.027 \\
TOM & 0.002 & 0.046 & 0.003 & 0.001 \\
Adjusted R squared & 0.011 & & & \\
\hline
\end{tabular}

\section{Conclusion}

Fama (1970) introduces the efficient market hypothesis which is based on the random walk theory. According to him, new information arrives in a random manner to the market; prices reflect this information directly and accurately. Thus, stock prices move randomly so that no investor can achieve abnormal returns by exploiting the price behavior in any investment strategy. Stock prices are unpredictable and technical analysis is useless. The 
presence of market anomalies violates the efficient market hypothesis. For example, calendar anomalies indicate that security prices goes up and down following certain trends based on seasonal effects. The day of the week effect implies that stock returns tend to be highest (lowest) on a certain day of the week. The month of the year effect and specifically January effect indicates that returns are maximum in January. The turn of the month effect means that most returns are achieved on the turning days of the calendar. This study investigates those three anomalies in ASE over the period 2002-2011. We apply OLS and GARCH $(1,1)$ regression analysis using dummy variables on both daily and monthly returns of the free float market index. The results contradict what is called Monday effect. The evidence show significantly higher returns on Sundays (the first day of trading of the week) and Thursdays (The last trading day of the week) than the other week days. Stock returns are highest on Sunday. Monday returns are significantly negative. Moreover, our findings provide a strong evidence of the January effect in ASE over the period of the study. Finally, consistent with previous studies there is a significant turn of the month effect.

\section{References}

Aggarwal, R., \& Rivoli, P. (1989). Seasonal and Day-of-the-Week Effects in Four Emerging Stock Markets. The Financial Review, 24(7), 541-550. http://dx.doi.org/10.1111/j.1540-6288.1989.tb00359.x

Agrawal, A., \& Tandom, K. (1994). Anomalies or the Illusions? Evidence from Stock Markets in Eighteen Countries. Journal of International Money and Finance, 13, 83-106. http://dx.doi.org/10.1016/0261-5606(94)90026-4

Alexakis, P., \& Xanthakis M. (1995). Day of the week effect on the Greek stock market. Applied Financial Economics, 5, 43-50. http://dx.doi.org/10.1080/758527670

Al-Jarrah, I. M., Khamees, B. A., \& Qteishat, I. H. (2011). The turn of the month anomaly in Amman stock exchange: Evidence and implications. Journal of Money, Investment, and Banking, 21, 5-11.

Al-Rjoub, S. (2004). The daily return pattern in the Amman stock exchange and the weekend effect. Journal of Economic cooperation, 25(1), 99-114.

Apolinario, R. M. C., Santana, O. M., Sales, L. J., \& Caro, A. R. (2006). Day of the Week Effect on European Stock Markets. International Research Journal of Finance and Economics, 2, 53-70.

Ariel, R. A. (1987). A Monthly Effect in Stock Returns. Journal of Financial Economics, 18, 161-174. http://dx.doi.org/10.1016/0304-405X(87)90066-3

Arsad, Z., \& Coutts, J. A. (1996). The Weekend Effect, Good News, Bad News and The Financial Times Industrial Ordinary Shares Index: 1935 - 9. Applied Economics Letters, 3, 797-801.

Barone, E. (1989). Italian Stock Market: Efficiency and Calendar Anomalies. Journal of Banking and Finance, 14, 483-510. http://dx.doi.org/10.1016/0378-4266(90)90061-6

Boudreaux, D. O. (1995). The monthly effect in international stock markets: evidence and implications. Journal of Financial and Strategic Decisions, 8(1).

Brooks, C. \& Persand, G. (2001). Seasonality in Southeast Asian Stock Markets: Some New Evidence on Day of the Week Effects. Applied Economic Letters, 8, 155-158. http://dx.doi.org/10.1080/13504850150504504

Brown, P., Keim, D., Kleidon, A., \& Marsh, T. (1983). New Evidence on the Nature of Size-related Anomalies in Stock Prices. Journal of Financial Economics, 12, 33-56. http://dx.doi.org/10.1016/0304-405X(83)90026-0

Cadsby, C. B., \& Ratner, M. (1992). Turn-of-month and Pre-Holiday Effects on Stock Returns: Some International Evidence. Journal of Banking and Finance, 16, 497-509. http://dx.doi.org/10.1016/0378-4266(92)90041-W

Cadsby, C. B., \& Torbey, V. (2003). Time-of-month anomaly: reality or mirage?. Applied Economics Letters, 10, 741-745. http://dx.doi.org/10.1080/1350485032000129584

Choudhry, T. (2000). Day of the Week Effect in Emerging Asian Stock Markets: Evidence from the GARGH Model. Journal of Financial Economics, 10, 235-242.

Choudhry, T. (2001). Month of the year effect and January effect: evidence from a non-linear GARCH model. Int. J. Finance. Econ., 6, 1-11. http://dx.doi.org/10.1002/ijfe.142

Connolly, R. A. (1989). An Examination of the Robustness of the Weekend Effects. Journal of Financial and 
Quantitative Analysis, 24, 133-169. http://dx.doi.org/10.2307/2330769

Cross, F. (1973). The Behavior of Stock Prices on Fridays and Mondays. Financial Analysts Journal, 29, 67-69. http://dx.doi.org/10.2469/faj.v29.n6.67

Doran, J., Danling J., \& Peterson, D. (2008). Gambling in the New Year? The January Idiosyncratic Volatility Puzzle. MPRA Paper 8165, University Library of Munich, Germany.

Dyl, E. (1977). Capital Gains Taxation and Year-end Stock Market Behavior. Journal of Finance, 32, 165-175. http://dx.doi.org/10.1111/j.1540-6261.1977.tb03250.x

Fama, E. (1970). Efficient Capital Markets: A Review of the Theory and Empirical Work. Journal of Finance, 25, 383-417. http://dx.doi.org/10.2307/2325486

Floros, C. (2008). The Monthly and Trading Month Effects in Greek Stock Market Returns: 1996 - 2002. Managerial Finance, 34, 453-464. http://dx.doi.org/10.1108/03074350810874415

Fountas, S., \& Segredakis, K. N. (2002). Emerging Stock Markets Return Seasonalities: The January Effect and the Tax-Loss Selling Hypothesis. Applied Financial Economics, 12, 291-299. http://dx.doi.org/10.1080/09603100010000839

French, K. R. (1980). Stock Returns and the Week-End Effect. Journal of Financial Economics, 8, 55-70. http://dx.doi.org/10.1016/0304-405X(80)90021-5

Gibbons, M., \& Hess, P. (1981). Day of the Week Effects and Asset Returns. Journal of Business, 54, 579-596. http://dx.doi.org/10.1086/296147

Giovanis, E. (2009). Calendar Effects in Fifty-five Stock Market Indices. Global Journal of Finance and Management, 1(2), 75-98.

Gultekin, M. N., \& Gultekin, N. B. (1983). Stock Market Seasonality: International Evidence. Journal of Financial Economics, 12, 469-481. http://dx.doi.org/10.1016/0304-405X(83)90044-2

Ho, P. C., \& Kok, K. L. (1995). Day-Of-The-Week Effect of the Malaysian Second Board Stock Market. Malaysian Management Review, 1-10.

Hui, T. K. (2005). Day-Of-The-Week Effects in US and Asia-Pacific Stock Markets during the Asian Financial Crisis: A Non-Parametric Approach. The international Journal of Management Science, 33, 277-282.

Jaffe, J., \& Westerfield, R. (1985). The Week-End Effect in Common Stock Returns: The International Evidence. Journal of Finance, 40, 433-454. http://dx.doi.org/10.1111/j.1540-6261.1985.tb04966.x

Keim, D., \& Stambaugh, R. (1984). A Further Investigation of the Week-End Effect in Stock Returns. Journal of Finance, 39, 819-835. http://dx.doi.org/10.1111/j.1540-6261.1984.tb03675.x

Keong, L., Yat, D., \& Ling, C. (2010). Month-of-the-year effects in Asian countries: A 20-year study (1990-2009). African Journal of Business Management, 4(7), 1351-1362.

Kunkel, R. A., Compton, W. S., \& Beyer, S. (2003). The Turn-Of-The-Month Effect Still Alives: The International Evidence. International Review of Financial Analysis, 12, 207-221. http://dx.doi.org/10.1016/S1057-5219(03)00007-3

Lakonishok, H. J., \& Levi, M. (1982). Week-End Effects on Stock Returns: A Note. Journal of Finance, 37, 883-889. http://dx.doi.org/10.1111/j.1540-6261.1982.tb02231.x

Lakonishok, H. J., \& Maberly, E. (1990). The Weekend Effect: Trading Patterns of Individual and Institutional Investors. Journal of Finance, 45, 231-243. http://dx.doi.org/10.1111/j.1540-6261.1990.tb05089.x

Lakonishok, H. J., \& Smidt, S. (1988). Are Seasonal Anomalies Real? A Ninety Year Perspective. Review of Financial Studies, 1, 403-425. http://dx.doi.org/10.1093/rfs/1.4.403

Maghayereh, A. (2003). Seasonality and January Effect Anomalies in an emerging Capital Market. Arab Bank Review, 5, 25-32.

Marrett, G., \& Worthington, A. (2011). The month-of-the-year effect in the Australian stock market: A short technical note on the market, industry and firm size impacts. Australasian Accounting Business and Finance Journal, 5(1), 117-123.

McGuinness, P. B. (2006). Turn-of the-month return effects for small cap Hong Kong stocks. Applied Economics Letters, 13(14), 891-898. http://dx.doi.org/10.1080/13504850500426046

Mehdian, S., \& Perry, M. J. (2002). Anomalies in US Equity Markets: A Re-Examination of the January Effect. 
Applied Financial Economics, 12, 141-145. http://dx.doi.org/10.1080/09603100110088067

Mills, T. C., \& Coutts, J. A. (1995). Calendar Effects in the London Stock Exchange FTSE Indices. European Journal of Finance, 1, 79-94. http://dx.doi.org/10.1080/13518479500000010

Mills, T. C., Siriopoulos, C., Markellos, R. N., \& Harizanis, D. (2000). Seasonality in the Athens Stock Exchange. Applied Economics Letters, 10, 137-142.

Ogden, J. P. (1990). Turn-of-month evaluations of liquid profits and stock returns: A common explanation for the monthly and January effects. Journal of Finance, 45(4), 1259-1272. http://dx.doi.org/10.1111/j.1540-6261.1990.tb02435.x

Patel, J. B. (2012). A further analysis of small firm stock returns. Managerial Finance, 38(7), 653-659. http://dx.doi.org/10.1108/03074351211233113

Pena, J. I. (1995). Daily Seasonalities and Stock Market Reform in Spain. Applied Financial Economics, 5, 419-423. http://dx.doi.org/10.1080/758538601

Pettengill, G., \& Jordan, B. (1988). A comprehensive examination of volume effects and seasonality of daily security returns. Journal of Financial Research, 11, 57-70.

Rezvanian R., Turk R., \& Mehdian S. (2008). Anomalous Behavior in Security Markets: Evidence from Equity Markets of the People's Republic of China. Retrieved from www.apeaweb.org/confer

Rodriguez, W. K. (2012). Day of the Week Effect in Latin American Stock Markets. Journal of Economic Analysis, 27, 71-89.

Rogalski, R. J. (1984). New findings regarding day-of-the-week returns over trading and nontrading periods: A note. The Journal of Finance, 39(5), 1603-1614. http://dx.doi.org/10.1111/j.1540-6261.1984.tb04927.x

Rozeff, M., \& Kinney, W. (1976). Capital Market Seasonality: The Case of Stock Returns. Journal of Financial Economics, 3, 379-402. http://dx.doi.org/10.1016/0304-405X(76)90028-3

Solnik, B., \& Bousquet, L. (1990). Day of the Week Effect on the Paris Bourse. Journal of Banking and Finance, 14, 461-468. http://dx.doi.org/10.1016/0378-4266(90)90059-B 